\title{
THE UNITED STATES AND NORTHEAST ASIA-LOOKING AHEAD
}

\section{Robert A. Scaloppini}

Historically, the foreign policy of the United States was focused mainly upon two regions: Europe and the Western Hemisphere. The reasons are easily understood. America's cultural heritage was overwhelmingly European. In addition, the countries of Western Europe dominated the globe; the U.S. itself had once been a colony, and the economic ties with such countries as Great Britain, Germany and France remained strong. Meanwhile, the Western Hemisphere represented our near neighbors and presented a combination of promise and problems, with two 19th Century conflicts (Mexico and Spain-Cuba) taking place. Earlier, through the Monroe Doctrine, the U.S. had attempted to declare the hemisphere off limits for Europe.

After World War II, however, a major shift began to unfold. The two original regions of primary commitment remained important, but the vast Asia-Pacific region, and especially Northeast Asia, rapidly emerged as Washington's central concern, whether the measurement is security, economics or politics. Two wars were fought in East Asia after World War II in the effort to prevent Communist expansion and preserve a balance of power. Economic relations between the U.S. and Asia assumed vital importance. And the United States took an active role in encouraging and supporting the broad trend from authoritarianism to democracy on the part of diverse Asian society.

To examine current trends and future prospects in the relations between the United States and the societies of Northeast Asia is thus essential if we are to glimpse the prospects of the 21 st Century. Since the U.S.-Japan relationship has had the longest continuity in its present form-nearly fifty years we can commence our survey with it. Few victors in war have been as generous to the defeated as was the United States to Japan in the aftermath of World War II. Economic assistance combined with political restructuring to enable Japan to reemerge as a stable, developing society within a decade after the war. To be sure, the Japanese deserve much credit. Policy combined with culture enabled the society to take maximum advantage of its new opportunities.

In the shadow of the Korean War, security ties were added to those in the economic and political field. A U.S.-Japan security alliance was formed that has now existed for almost a half-century, and provides the foundation for the Ameri- 
can strategic commitment to the region as a whole. Meanwhile, as Japan rose to become the second largest economy in the world, the economic relations with the United States reached commanding proportions, of critical importance to both nations. The two countries also shared a commitment to democracy, although the nature of informal politics, as opposed to institutional politics, differed significantly, testimony to two very different cultural backgrounds.

Successive American Presidents have pronounced the U.S.-Japan relationship the most important bilateral relation for the United States now existing. Like all international relations, this relationship is not without its problems. On the strategic front, however, there are few difficulties in so far as the U.S. is concerned. The trend recently has been to heighten the Japanese commitment. If the revised guidelines first proposed by President Clinton and Prime Minister Hashimoto in 1996 are approved by the Diet, Japan would be able to extend its military activities short of combat considerably in the event of conflict, and the area to be covered would be less restricted. Further, Japan is considering cooperation with the U.S. or an independent program in developing a Theatre Missile Defense system (TMD), a move greatly stimulated by the August 31, 1998 North Korean firing of a three-stage missile, with the last stage taking it over Japan. An independent intelligence satellite system is also being contemplated. In addition, support has grown for amending Article Nine of the Japanese Constitution so as to give Japan greater military flexibility.

These developments go in the direction of meeting the American demand for greater cost and risk-sharing on the part of its allies. Yet in truth, the United States has never been certain of what it want Japan to do with respect to security policy. It does not want a nuclear Japan: or does it want Japan to develop an independent, high-posture military policy. But it has wanted Japan to share more fully the burdens of maintaining a balance of power. Meanwhile, some Japanese have asserted that without full rights in the realm of military policy, Japan will never be accepted as a major power. Why is Japan not a permanent member of the Security Council? They ask, noting that all such members are states possessing full military rights, and in addition, are nuclear powers.

The sentiment in Japan for moving toward full military parity with other major states still represents the views of a distinct minority, and as long as the U.S. commitment is credible and no major threat is perceived, that is likely to continue. The concerns expressed by neighboring states about the restoration of Japanese militarism are exaggerated. Yet nationalism is rising in Japan as elsewhere in Asia, and the desire to have a status equal to its regional and global 
role is gaining strength. The drive for permanent Security Council membership will continue. Thus, the capacity and will of the U.S. to support the security alliance, and equally important, the creation of more adequate multilateral security structures for the region will be important in the years ahead.

On the economic front, the scene represents a combination of vital importance to both nations and recurrent tensions. The recent trade imbalance has been huge. Estimates are that the deficit for the U.S., totaling $\$ 55.7$ billion in 1997, may have reached nearly $\$ 70$ billion in 1998. The rapid rise in the Yen in recent months combined with some decline in American demand may reduce the imbalance with Japan in the period immediately ahead. Yet as U.S. trade representative Charlene Barshefsky said, the current American trade deficit, totaling an estimated $\$ 240$ billion in 1998, is conducive to the rise of U.S. protectionist sentiment, and that can be seen in terms of the demands for protection of steel and certain other key products.

Thus, the United States has put unremitting pressure on Japan in recent years to open its markets more broadly and permit greater investment access. Manufactured imports account for only $4 \%$ of the Japanese economy, half the percentage of U.S. imports, and direct foreign investment in Japan is less than one-half of $1 \%$ compared to more than $7 \%$. In the U.S. Yet with the economic picture in Japan increasingly cloudy in recent years, and Japanese politics close to stalemate, movement has been slow. Fundamental economic change in Japan, moreover, involves cultural change, never a development that can be easy or rapid.

Yet with internal pressures gradually added to external ones, Japan has adopted a major economic stimulus package amounting to nearly $\$ 200$ billion, and has also launched aid programs for other Asian societies, another American demand. It remains to be seen, however, whether the measures thus far taken will bring the Japanese economy out of recession. Meanwhile, resentment against American pressure has caused some Japanese to join other Asians in decrying U.S. "bullying."

In the decades ahead, Japan is virtually certain to remain a major economic force in Asia and in the world. It now stands on the frontiers of science and technology, capable of innovating as well as borrowing. Its people are committed to further development and have the requisite skills. And its economy will be internationalized on an ever more intensive scale. At the same time, challenges lie ahead, chief among them the aging of Japan's population. By 2015, onefourth of that population will be 65 years of age or older. The implications in 
terms of social security costs and the labor market are huge. It will be critical that Japan and the U.S. cooperate closely in advancing the upper scale of their service economies and at the same time, making globalization safer and more effective for all nations.

Japan is also destined to pay a higher cost for modernization in terms of social pressures. Crime will increase from the current low rate, as will divorce. Generational differences will continue to expand. In these respects, the U.S. and Japan will develop a greater commonality as two leading post-modern societies, making more extensive cultural interaction important, especially between younger generations.

Democracy - and the problems it presents - will continue to be a common bond between the two countries. Money politics, issues of leadership, and the worrisome problem of electorate indifference warrant continuous attention. On the security front, the threat in Asia is less likely to be that of a major power conflict, and more likely to be domestic violence within failing states, terrorism by disaffected individuals and groups, and ethnic-religious cleavages turned violent. Yet the issue of divided states - the two Koreas and China-Taiwanrepresent formidable problems, susceptible to conflict. Further, relations between India and Pakistan, and India and China, remain worrisome. Hence, the need for effective multilateral security mechanisms will grow in the years ahead, and both the U.S. and Japan must play a role in this respect.

Finally, for these two nations, it will be critical to take leading roles in seeking to reach broad agreements with others on the issues of resource management, pollution control, and scientific agriculture - the survival issues of the next century.

In sum, there are strong reasons to believe that the relationship between the United States and Japan will continue to be important not only to these two nations, but to the peace and prosperity of the Asia-Pacific region as a whole, and especially to Northeast Asia.

Turning to the United States and China, the picture is at least equally complex. In the years since the Tiananmen Incident of 1989, relations between these two countries have generally improved. The reasons are several. First, the leaders of both nations came to realize the importance of a positive relationship in terms of virtually every issue confronting the region. Second, China discovered that the U.S. President does not make foreign policy alone; consequently, it sought ways to reach Congress and the American public, seeking to improve its image. Third, economic relations between the two nations advanced rapidly 
notwithstanding various problems, and the U.S. business community increasingly supported a policy of engagement with China. Finally, the ideological barrier was further reduced, with a greater element of pragmatism operative in China.

At the same time, as the 20th Century comes to a close, this relationship faces various challenges. On the strategic front, gains have been made: regular military exchanges and conferences have been held; in 1998, for the first time, a joint U.S.-PRC search and rescue exercise took place; and transparency was increased, symbolized by the visit of Secretary of Defense Cohen to a oncesecret defense center in Beijing.

Yet in late 1998, a bipartisan House of Representatives committee prepared a report asserting that in the last twenty years, China had obtained sensitive American military technology, some through sales such as satellite exports, some through other means. Controversy over past Chinese technology transfers to Iran and Pakistan has also erupted, although the Chinese currently assert that the sale of missiles to Iran has been halted. Further, China has indicated serious concern about the projected U.S. Theater and National Missile Defense programs, especially as TMD may relate to Taiwan and Japan.

Indeed, the key issue between the two countries according to Beijing is that of Taiwan. China insists that the U.S. must abide by the pledges contained in the Three Communiquйs as it interprets these documents, namely, an acceptance of One China and Taiwan as a part of China, and opposition to the inclusion of Taiwan in any organization composed of sovereign states. It also asserts that military sales to Taiwan constitute interference in the internal affairs of another state. The United States walks cautiously along two paths: The Three Communiquйs and the Taiwan Relations Act. Under provisions of the Act, military sales continue and that is not likely to change. And while the U.S. privately admonishes Taiwan to avoid provocative actions and makes clear its opposition to any declaration of independence, Taiwan's image in the United States is generally good, with its economic progress and democratic system lauded.

The Taiwan issue will not disappear. While high level talks between Taiwan and China have taken place in the recent past, and economic and cultural relations have both expanded significantly, the critical political issues remain unresolved. Taiwan insists that it remains a separate, sovereign entity, and warrants equality with the PRC in all negotiations. The Kuomintang and the Democratic Progressive Party have drawn closer together in views and policies recently, with the latter eschewing a formal declaration of independence, and the 
former using terms like sovereign in describing the current status of Taiwan. Thus, the political gap between the PRC and Taiwan remains large. The critical issue at present is whether both sides can live with the status-quo, even though it is certain to be a dynamic status-quo, with changes often taking place or sought by one party or the other.

U.S. policy on the issue of force is one of conscious ambiguity. The United States will not state precisely what it would do in the event the PRC elected to use force against Taiwan. To guarantee support for Taiwan would aid the independence movement; to pledge non-involvement would aid the hard line elements in Beijing. Moreover, either position would deeply split the American community. Hence, the U.S. restricts its views to urging a peaceful settlement, and. until that is achieved, a willingness to live with the conditions that exist.

Another issue relates to Tibet and the Dalai Lama. Once again, the U.S. has urged discussions between Beijing and the Dalai Lama, but China insists that he first aver his support for One China, state that Taiwan is a part of China, and disavow all separatist activities. Thus far, no official discussions have taken place. Meanwhile, the recent visit of the Dalai Lama to Washington, and his informal meeting with President Clinton among others aroused Beijing's wrath.

Human rights within China have been an additional recurrent subject of controversy. In recent times, China has signed the International Covenant on Political and Human Rights, and a greater quotient of political flexibility exists than at any time in PRC history. The broad movement is from Leninism to authoritarian pluralism, namely, a politics that is still restrictive, but less rigid, a more active civil society separate from the state, and a mixed economy with the private sector playing an ever larger role. While there will be retreats on occasion, a fundamental reversal of these trends is highly unlikely.

The current scene illustrates these facts. Generally, the freedom to talk and even to publish some materials critical of current policies has expanded. Yet those who seek to organize an opposition party or engage in extensive criticism in print are punished. With signs of peasant and labor unrest increasingly prominent, the Beijing government is concerned about stability. But it is also a time of testing for those who would oppose-to determine what can and cannot be done.

The United States will remain critical of acts considered violations of human rights. China will continue to charge the U.S. with seeking to implant its system on others, thus interfering in China's domestic affairs. Moreover, it will denounce the "univocal world" now perceived to exist, and call for multipolarism even as it seeks to create "strategic partnerships" with the large states on a 
bilateral basis.

Looking ahead, China will be a major power in the coming century, but one facing major problems. The modernization of 1.3 billion people, eventually to be at least 1.6 billion, is not easy. Economic difficulties and regional differences will persist. Hence, the gamble of all of China's neighbors is that a combination of domestic challenges and growing economic internationalization will cause China to pursue a moderate, peace-oriented foreign policy, thereby matching deeds with China's words - truly peaceful coexistence. Yet given its military modernization and advancing economic strength, China's actions will be watched carefully by all others.

U.S. policy toward China will be characterized by continued efforts to affect a relationship that is on balance positive, employing a combination of incentives and deterrents to encourage the positive interaction of China with others in the region. Given the common interests that now exist, cautious optimism with respect to Sino-American relations is warranted - without minimizing the issues to be faced.

Meanwhile, relations between the United States and the two Koreas constitute another crucial element in the East Asian picture. Since the accession of Kim Dae-Jung to the Presidency in early 1998, U.S-ROK relations have been very good on balance. In seeking to alleviate South Korea's serious economic distress, President Kim has supported economic policies favored by the IMF and the U.S., with some signs of progress after many months of pain. Advances in ROK-Japan relations have also been heralded by Washington. Further, Kim's efforts to improve relations with the North have generally met with Washington's support. In turn, Seoul has continued to urge the U.S. to uphold the Agreed Framework Agreement of October 1994 between the U.S. and the DPRK, and to move forward with the KEDO program dedicated to constructing a Light Water Reactor for the North.

There are certain problems. As in the case of Japan, the U.S. wants the ROK to open its markets more fully, and carry out its promised program to reduce cartelization, a difficult task given the attitude of the cabal (big combines) and the labor unions. In both countries, moreover, opinion is deeply divided over the issue of policies toward the DPRK, with a sizeable group believing that a tougher policy should be enforced. Indeed, given the North's recent actions and rhetoric, the skeptics in the U.S. and the ROK have increased in numbers, despite such events as the access given Hyundai to promote tourism and economic development in the Mt. Kumgang area of the North. On 
balance, however, U.S.-ROK relations are better than at any time in the recent past, and the strategic alliance is firm.

Relations with the DPRK remain minimal and troubled. Pyongyang is angry with the U.S. because of the slowdown in pledged heavy oil shipments, and the delays in carrying out KEDO.

Negotiations on such matters as the underground facility suspected by some Americans of being constructed for purposes of resuming nuclear activities, have been exceedingly difficult. Nonetheless, small energy and agricultural teams have come to the United States to interact with American counterparts, and meanwhile, five individuals were sent to Australia National University for a one-year training program in business, with American Foundation funding. Another group was studying legal matters in Beijing with an American supervisor. Slowly and with great caution, the DPRK is turning out, with modest American assistance.

Will Korean reunification cause a major change in U.S. policy toward the peninsula? The critical issue here is when and how will reunification take place? If it comes quickly, and through some form of North Korean collapse, the South will be in great need of economic support, and will also experience severe political problems in the effort to absorb - or keep separate-some twenty-two million people accustomed to a very different political order. The United States together with Japan and China would undoubtedly render assistance, yet possibly with some degree of rivalry or tension.

If reunification takes place peacefully, through an evolutionary process, and over a protracted period of time, the American role will presumably be one of increasing interaction with the North, both economic and cultural, while maintaining a firm commitment to the South. After reunification, the Korean people will decide whether a strategic connection with the U.S. is necessary and desirable, an issue that will also require the decision of the American people. Neighboring states, and especially China, will be deeply concerned with this matter.

Whether Korea elects to maintain a strategic tie with the U.S., possibly based on sea and air power rather than ground forces, or seeks a balanced, equidistant relation with all major powers will be an issue for the future-but with lessons from the past no doubt seriously restudied.

Let us next turn to U.S.-Russia relations. While the Russian Federation is a Eurasian nation, with much of its attention devoted to Europe, the Middle East and South Asia, it also has a vital stake in East Asia, and particularly Northeast Asia. At present, relations between Moscow and such regions as Primo sky 
(with its capital, Vladivostok) are troubled. For some seventy years during the Soviet era, the Russian Far East sent its products, including extensive military items, to Moscow and was subsidized in exchange. Now this system has broken down, and the economy of the Russian Far East is deeply depressed. Even the RFE military has been affected, with much equipment obsolete and the morale of the armed forces low.

Nevertheless, given its resources, the Russian Far East can be a vital part of Northeast Asia once economic recovery takes place. At some, point, it will play a prominent role in the creation of 4 Natural Economic Territory (NET) comprising the states bordering the Sea of Japan (East Sea). A NET is an economic entity that crosses political boundaries, combining resources, manpower, capital and technology to mutual advantage between or among states or portions of states having geographic proximity and complimentary capacities. Pipelines will eventually connect Siberia with key Asian regions, with metal production also an important link along with joint jurisdiction over fishing. Foreign investment will abet the development of the RFE and immigrant labor will be a prominent issue.

Despite efforts to maintain closer ties, U.S.-Russian relations have been troubled recently by a series of problems. Washington has been unhappy with the inability of Russian leadership to get their economic house in order, and the near-chaos prevailing in the political realm. Russia has deeply resented the expansion of NATO despite some efforts to adjust to that development, and now, it strongly criticizes the U.S. plans with respect to missile defense, including the possible involvement of Japan. Thus, the Duma has not ratified START II at this point, thereby delaying the process of denuclearization. Meanwhile, there is increasing concern over the possibility of an accident with respect to Russia's aging nuclear stockpiles.

Recently, Russia and China proclaimed a "strategic partnership," with the proclamation that "hegemony" should be resisted, and multipolarism sought. Yet the U.S. is not deeply concerned about a revived Sino-Russian alignment. Russia - and in particular, the Russian Far East - is deeply conscious of the massive nation to the south. Given the sparse population of the latter region, with scarcely 8 million people in residence, the possibility of a wave of Chinese migrants, however improbable, is worrisome. Further, while an important agreement has been reached among Russia, China and the three Central Asian states regarding demilitarization of the border and troop reduction, Central Asia will always be a contested area in so far as the two giant neighbors are concerned. In 
South Asia also, the alignments are in opposition.

Russia is also having problems in achieving a peace treaty with Japan by the year 2000, as has been pledged. The key issue remains the so-called Northern Territories, or in Russian parlance, the South Kuris. It now seems unlikely that Moscow will cede any territory to Japan, given strong nationalist opposition. Joint development may not suffice for Tokyo. Thus, a settlement in not presently in sight.

Against this background, U.S.-Russian relations might logically be expected to improve, the strategic issues notwithstanding. However, the road is likely to be rocky. A combination of NATO expansion and TMD $\backslash$ NMD development may lead to a growing Russian sense of threat, especially given its economic limitations at present. Already, individuals like Evgeny Primakov have sought to reestablish Russia as a global power, waving aside the "Westernizes" who wanted a closer alignment with the U.S. and the EU.

Nonetheless, if the United States persists in seeking to provide Russia with some economic aid and political support, meanwhile attempting to reassure Moscow that missile defense is not aimed at it, and NATO poses no threat, relations may improve. In the final analysis, the threats to Russia are firstly domestic, and in secondary terms, the attitudes and policies of diverse neighbors over the next several decades. Weak neighbors, threatened with internal violence combine with others growing increasingly strong. And Russia itself faces the prodigious task of reconstructing a nation shattered by recent events. A strong, supportive America could be an asset.

Finally, let me turn to Mongolia, a nation small in population, but large in area and located in a strategically position of great importance. In recent times, Mongolia has faced the problems of departing from both a system and a sponsor. In the Soviet era, a rigid authoritarian socialist order at home was bolstered by the military power and economic assistance of the Soviet Union. Not surprisingly, the transition to a democracy with a market orientation has been fraught with difficulties.

In this setting, the United States has acted in both official and non-official capacities, with the latter perhaps being the most significant. Assistance has been given by such organizations as the Asia Foundation and the Sores Foundation to strengthen the legislative system, to help in creating a reformed legal structure, and to assist in the training of diverse individuals. Institutes in the United States and Mongolia have cosponsored international conferences, with the effort to reach a common understanding regarding regional problems and 
bilateral relations.

Given its geographic position, Mongolia must maintain a foreign policy dedicated to balanced relations with all of the major powers. The close presence of China and Russia dictates that special attention is given to expanding relations with Japan and the United States. There is safety in numbers. Hence, current American policies generally touch a receptive audience in Ulaanbaatar.

In conclusion, how should one view current U.S. policy with respect to the nations of Northeast Asia, and prospects for the future? American ties with the major powers of the region will always be complex, with some combination of cooperation and tension. The task will be to keep bilateral relations on balance favorable, and that is eminently possible. No major state wants a conflict with another, given the devastating costs of modern war. The focus of each state is firstly on domestic challenges as the global revolution advances with accelerating speed. One of the rising challenges is likely to terrorism at home, as dissidents obtain weapons of great destructive capacity.

Bilateral relations between key nations will continue to be vitally important, but we are progressively moving into an age of multilateralism. In its initial stages, multilateral institutions, especially those devoted to peace making and peace keeping, are fragile, with decisions difficult to reach and to enforce. Yet over time, such organizations as a Northeast Asian Security Dialogue will emerge, with increasing impact on the region.

Meanwhile, modem weaponry is changing the nature of security. With intercontinental missiles and diverse weapons of mass destruction proliferating, future war involving major states, if it concurs, will affect cities and civilians as much as military forces. Further, rapid deployment rather than ground forces in foreign bases will be the trend. However, the United States will not remove its forces from Japan and South Korea prematurely, thereby creating instability throughout the region.

Efforts should also be expended to make the development of missile defenses as non-threatening as possible.

The United States will remain deeply engaged in Northeast Asia for economic and political as well as security reasons. Learning how to live with globalization will remain a foremost challenge, and the U.S. will remain a key factor. Its economy will become increasingly intertwined with that of others, and from time to time, protectionist sentiments will be loudly voiced. However, given American interests, the commitment to free trade and open markets will remain dominant. 
As noted earlier, American cooperation with others in tackling more seriously the issues of resource management, environmental pollution, and population trends will be critically important. These issues are vital to the future of Northeast Asia, and they have thus far received too little sustained attention. The U.S. can and must harness its scientists to its governmental officials, working with others on these tasks.

The U.S. commitment to political openness will continue, but Washington must guard against arrogance, and accept the fact that certain nations are not prepared for democracy, given their stage of development and cultural antecedents. The argument about Asian values versus Western values is largely sterile since there are many differences within both Asia and the West. Even within a given society, life-styles and commitments vary greatly. Note the difference between an educated Shanghai youth and a middle-aged Gansu peasant. Furthermore, in this period of rapid change and intensive cultural interaction, where are there pure cultures and values? The supreme challenge is to adjust to the complexity of modern life, and meeting that challenge is paramount for the United States and its citizens, as it is for others.

In sum, the United States will pursue two broad approaches in its Asian policies: the construction of a coalition of powers and of a balance of power. Coalitions will be created to tackle specific issues or problems like that of a divided Korea. They will be built by bringing together those states that have a common interest in solving the issue at hand; hence, they will vary in composition with the issue. At the same time, given the strong nationalism now present in Asia, the commitment to weapon modernization, and the many unresolved problems, it will be essential to maintain a balance of power. These two commitments are not incompatible, as some critics aver. Indeed, in varying degree, they are already present.

On balance, one can view the future with cautious optimism. The age ahead will be one of continuous, rapid development for all of the societies of Northeast Asia, albeit, with occasional adverse cycles. With cultural exchange growing, the capacity for greater understanding, as well as more extensive borrowing will exist. All nations must take advantage of the opportunities that are now on the horizon. 